Емилија Јовић

Универзитет у Нишу

Филозофски факултет

Департман за руски језик и књижевност

emilija.jovic@filfak.ni.ac.rs
УДК 811.161.1'255'373.7:811.163.41'255'373.7

https://doi.org/10.18485/slavistika.2021.25.2.10

Оригиналан научни рад примљено 7.4.2021.

прихваћено за штампу 6.10.2021.

\title{
О ОСОБЕНОСТИМА ТЕХНИКЕ ПРЕВОЪЕҢА СОМАТСКИХ ФРАЗЕОЛОГИЗАМА СА РУСКОГ НА СРПСКИ ЈЕЗИК
}

Предмет нашег истраживања чине соматски фразеологизми и анализа фактора који утичу на разумевање и могућност превода са руског на српски језик код оних говорника којима је руски језик нематерњи. Издвајање основних принципа којима се дефинишу могућности превода ових специфичних лексичких јединица у свести говорника руског језика као страног један је од основних задатака нашег рада. По правилу, фразеологизам се преводи фразеологизмом, али то, као што је познато, није увек могуће, па се зато за сваки конкретан случај превођења соматских фразеологизама користе различите методе. Циљ нашег рада је дефинисање основних фактора који утичу на могућност превођења соматских фразеологизама код говорника руског језика.

Кључне речи: соматски фразеологизми, техника превођења, руски језик, српски језик.

The subject of our research is somatic phraseology units and analysis of factors that affect the understanding and possibility of translation from Russian into Serbian of speakers for whom Russian is a non-native language. Highlighting the basic principles that define the possibilities of translating these specific lexical units in the consciousness of Russian foreign language speakers is one of the basic tasks of our work. As a rule, phraseology is translated by means of phraseology, although this is not always possible, so each specific case of translating these lexical units requires the use of different methods.

Keywords: somatic phraseology, translation of phraseology, Russian language, Serbian language.

\section{1. Увод}

Према мишљењу Л. И. Ројзензона, фразеологија представља једну од најоригиналнијих, најсложенијих и најкомпликованијих творевина човекове језичке даровитости (Ройзензон 1973: 46). Она сажима читав сложени комплекс културе и психологије једног народа, као и јединствен начин његовог мишљења. Савремена истраживања у датој области су посвећена питањима семантике, унутрашње форме фразеолошких јединица ${ }^{1}$, њихове везе са концептима и улогом културолошког дискурса у образовању сличних јединица. Зато проучавање фразеологије подразумева коришћење различитих метода и података бројних лингвистичких дисциплина, као што су лексикологија, лексикографија, стилистика, етимологија, лингвистика текста и др.

Фразеологизми у различитим језицима, у нашем случају руском и српском језику, имају специфични карактер, због чега при дословном превођењу са једног на други језик не може увек бити пренесена експресија, конотација, односно изворно значење ФЈ из језика оригинала. Разлике у језичким сликама,

\footnotetext{
${ }^{1}$ У даљем тексту рада користићемо скраћеницу ФЈ као прихваћену у литератури.
} 
култури, погледу на свет различитих народа условљавају понекад да се за адекватан превод не може наћи одговарајући фразеолошки еквивалент. Приликом преношења фразеологизама са језика оригинала на језик превода, фразеологизми често у потпуности мењају своје значење. Зато је истраживање могућности превођења соматских фразеологизама један од главних задатака у нашем раду.

\section{1. Теоретски оквир и претходна истраживања}

Под фразеолошком јединицом подразумевамо самосталну, номинативну језичку јединицу која представља устаљену групу речи, којима се изражава свеукупно фразеолошко значење и по функцији је слична засебним речима. Будући да су групе речи или синтагме тесно повезане са условима места и времена у којима је настала дата фразеолошка јединица, оне су јединствене и понекад је врло тешко, али не и немогуће, превести их са језика оригинала. Фразеологизми су, за разлику од од обичних лексичких јединица (речи) сложенији по свом саставу, тј. садрже неколико елемената који имају јединствено значење, затим, одликују се и постојаношћу састава и устаљеном граматичком формом, нпр. фразеологизам греть руки не може се заменити са греть руку или нагревать руки.

Фразеологизми су информативне језичке јединице које одражавају човекове представе и његов емоционални однос према средини која га окружује. Ово тврђење је истинито, тим пре што се “човеков живот, осмишљен кроз категорије друштвене свести, фиксира, интерпретира и уопштава кроз категорије језичке свести које се вербализују системом лексичко-фразеолошких средстава" (Алефиренко 2008: 18).

Због сложености своје семантичке структуре и високог удела конотације у њима, фразеологизми, ступајући у различите везе, у различитим контекстима, добијају и додатне смисаоне и асоцијативне карактеристике. Осим тога, будући да представљају устаљене и засебно оформљене изразе, допуштају настанак различитих структурно-семантичких промена у говору, укључујући и веома сложене преформулације које би, иначе, биле немогуће у речима (Кунин 1996: 199). Тако, знајући за фразеологизам потупить голову, не можемо рећи ниже потупить голову или ещзе ниже потупить голову. Већина фразеологизама, дакле, има устаљен састав, мада постоје и фразеологизми где је могућа замена места у реду речи, нпр. набрать в рот воды - в рот воды набрать. Најчешће је та замена могућа код фразеологизама који се састоје из глагола и именских речи које зависе од њих.

Према мишљењу Драгане Мршевић-Радовић, уз помоћ фразеологизама представљамо човеков унутрашњи свет и оно што га окружује, те су зато њихов најважнији извор човекова природна средина, његове активности и професионални живот (Мршевић-Радовић 1987: 25). Са друге стране, аутор А. Менац (Менац 1995: 162) дефинише фразеологизам као спој две или више речи који се не ствара у говорном процесу, него се репродукује у готовом облику и има сталан састав и распоред саставница. Њима додајемо и дефиницију Рајне Драгићевић која под фразеологизмом такође подразумева устаљену језичку јединицу која се састоји од најмање две речи и има јединствено значење, без могућности мењања реда речи и самих речи у њима (Драгићевић 2008: 24). 
На крају, веома важна одлика фразеологизама су метафоричност и сликовитост, будући да њима не именујемо само предмете, појаве, особине, већ и њихову емоционалну и сликовиту позадину. Због свега тога су фразеолошке јединице и многозначне.

У нашем раду посебну пажњу обраћамо и на семантички план ФЈ, ослањајући ce, пре свега, на разлику између глобалних и компонентних фразеологизама. Глобалне фразеологизме карактерише узајамна зависност између речи које их чине, те се опште, глобално значење изражава фразеологизмом у целини (Мршевић-Радовић 1987: 63 - 72). Са друге стране, фразеологизми у којима једна јединица представља главну компоненту и носиоца семантичког значења, а друга компонента обавезну структурну компоненту употребљену у једном од својих значења јесу компонентни фразеологизми (говорити НА СВА УСТА = говорити МНОГО).

Проблему превођења фразеологизама посвећено је доста пажње у теоријским радовима из областипревођењалепекњижевности, затиму бројнимпубликацијама из области конфронтационе и контрастивне лингвистике ${ }^{2}$. Фразеолошки фонд, захваљујући преовладавању конотативног елемента у значењу ових лексичких јединица, у најбољој мери одражава културолошко-националну специфику једног одређеног језика. Управо због тога на највеће потешкоће наилази се при покушају њиховог превођења са једног на други језик.

\section{2. Методе превођења фразеолошких јединица}

В. С. Виноградов (Виноградов 2004) издваја 4 врсте, тј. 4 могућности за пренос садржаја фразеолошких јединица:

1) фразеологизам се преводи фразеологизмом (пренос подразумева идентично значење, исту стилску обојеност, као и унутрашњу форму), као у примерима: яблоко раздора, Ахиллесова пята, длинный язык / јабука раздора, Ахилова пета, дугачак језик;

2) еквивалентне фразеолошке јединице у језику превода (значење и стилска обојеност идентичне оригиналу, док унутрашња форма датих јединица одговара само у погледу карактера сликовитости) или такозвани делимични еквиваленти: белая ворона, вести двойную игру / бела врана (птица), играти двоструку игру;

3) стилски еквивалентан фразеологизам у језику превода са истим или сличним значењем, али другачијом унутрашњом формом (убить двух зайцеев, считать ворон, куда глаза гладят / убити две муве једним ударичем, бројати овце, куда год те очи воде) и

2 Досадашња истраживања соматских фразеологизама претежно се ослањају на корпусна истраживања конкретних соматских компоненти на когнитивној основи: “HANDS" IN RUSSIAN AND ENGLISH LINGUSTIC CONSCIOUSNESS ауторке Светлане Боголепове, CULTURAL MEANING OF BODY PARTS NAMES (in the English and Russian languages) Јулије Башкатове, слависта Абдулах Мушовић пише о синтаксичкој функцији ових лексичких јединица (Соматске фразеолошке јединице за изражавање емоиија и юихова синтаксичка функиија). 
4) у језику превода постоје речи са одговарајућим значењем и стилском обојеношћу (превод је могућ уколико нема наговештаја 'слике' која се налази у основи ФЈ, ако нема више планова у доживљавању датог израза, нпр. держать в ежовых рукавицах / бити чврсте руке, челичне песнище, владати попут тиранина. Дакле, преноси се само смисаона, емоционална, стилска и функционална информација карактеристична за фразеологизам у језику оригинала (Виноградов 2004: 188).

Са тачке гледишта преводилаца, фразеолошке јединице деле се на оне које имају еквиваленте у језику превода и на безеквивалентне фразеолошке јединице. Еквиваленти ФЈ могу бити потпуни и непотпуни.

а) Потпуни еквиваленти су они који се са фразеолошком јединицом из језика оригинала слажу у значењу, лексичком саставу, сликовитости, стилској усмерености и граматичкој структури. У такве фразеологизме убрајамо ФЈ интернационалног карактера засноване на митолошким предањима, историјским чињеницама и фразеологизме библијског порекла (Ахиллесова пята, брать грех на душу, в поте лица).

б) Делимични еквиваленти, преносећи значење садрже лексичка, граматичка и лексичко-граматичка размимоилажења. Зато можемо говорити о томе да је делимични еквивалент по степену адекватности превода равноправан са потпуним еквивалентом.

Помоћу еквивалентних јединица се преводи интернационална фразеологија, у коју спадају фразеолошке јединице које су ушле у различите језике из историјских извора, митологије или позајмљивањем из других језика или су се појављивали код различитих народа независно једни од других услед заједништва људског мишљења, близине различитих страна социјалног живота народа, њихове радне делатности и сл. Као основни начини превођења фразеологизама издвајају се фразеолошки и нефразеолошки превод који подразумевају да се фразеологизми преводе или одговарајућим фразеологизмом у језику превода или ако он изостаје неким другим језичким средствима. Многи лингвисти (Арсењева 1989, Виноградов 1972, Влахов, Флорин 1980 и др.) предлажу тако неколико метода превођења фразеологизма који конкретизују ова два основна начина превођења:

1) фразеолошки превод подразумева коришћење у тексту превода устаљених јединица различитог степена блискости између лексичких јединица језика оригинала и одговарајућих јединица у језику превода - од потпуног и апсолутног еквивалента до приближног фразеолошког значења; у оквиру овог превода издвајају се:

а) метод фразеолошког еквивалента и

б) метод фразеолошког аналога.

Уз помоћ првог метода чува се читав скуп значења јединице која се преводи. У том случају у језику превода постоји фразеологизам који се поклапа по свим параметрима са фразеолошком јединицом из језика оригинала. Независно од контекста такав фразеологизам има идентична денотативна и конотативна значења. Између две фразеолошке јединице у том случају нема разлика у односу смисаоног садржаја, стилске припадности, метафоричности и емоционал- 
но-експресивне обојености. Обе варијанте имају приближно једнак структурни састав као и ред идентичних лексичко-граматичких показатеља: слагање, припадност једној граматичкој категорији, употребљивост итд. Као примере наводимо следеће соматске фразеологизме: в мгновение ока / за трен ока; вырастать в глазах кому / расти (порасти) у (нечијим) очима.

Коришћење овог метода при превођењу омогућава да се у најбољој мери пренесе са једног на други језик један фразеологизам. Премда, треба поменути и неке ситуације које ограничавају употребу метода фразеолошког еквивалента. Наиме, фразеолошких еквивалената је далеко мање, затим приликом позајмљивања једног истог фразеологизма у оба језика у једном од њих може доћи до промене форме саме фразеолошке јединице, што је чешћи случај од претходно наведеног.

Други тип фразеолошки одговарајућих средстава су тзв. фразеолошки аналози. У случају изостанка фразеолошког еквивалента бира се фразеологизам са истим пренесеним значењем, заснованим на другачијој језичкој ситуацији. Такви су примери: показать нос кому / показати зубе некоме. Фразеолошки аналог се сматра пунозначним поклапањем превођене фразеолошке јединице с тим што се од ње разликује по неком показатељу: различита компонента, мале измене у форми, различита синтаксичка структура и др.

Код нефразеолошког превода, значење фразеолошке јединице се преноси помоћу лексичких, а не фразеолошких средстава у језику превода. Он се обично користи када није могуће наћи фразеолошки еквивалент или аналог. Овај превод, узимајући у обзир и компензационе могућности контекста, тешко можемо сматрати пунозначним због бројних недостатака и губитака у сликовитости, конотацији, експресивности и нијансама у значењу. У методе нефразеолошког превода убрајају се: лексички превод, калкирање и описни превод.

Лексички превод се примењује онда када се појам у једном језику описује фразеологизмом, а у другом уз помоћ речи. Код оваквог превода неопходно је тежити макар ка делимичном очувању сликовитости дате јединице у преносу значења њених засебних елемената.

Калкирање или дословни превод применљив је у оним случајевима када друге методе, посебно фразеолошког типа, не могу да пренесу сематничко-стилско и експресивно-емоционално значење фразеологизма. Ова метода, како се истиче у литератури, корисна је када је неопходно пренети игру речи из оригинала (Виноградов 2004: 191).

Описни превод се своди на објашњење фразеологизма, на превод фразеолошке јединице помоћу слободног слагања речи. Овом поступку се прибегава само када у потпуности изостаје пуни еквивалент у језику превода, при чему се могу користити појашњења, описивање или чак пословице и брзалице како би се што краће и упечатљивије пренео садржај фразеологизма. Описни превод је посебно користан при преносу терминолошких конструкција које не подлежу буквалном преводу. Свеједно, и код ове методе превођења неопходно је тежити фразеологизацији или макар наговештају на конотативна значења (Комисаров 1990: 252).

Због свега овога превод фразеолошких јединица неретко представља озбиљан и тежак задатак, пре свега због њихове експресивности, стилске маркираности и национално-културолошке специфичности. 


\section{2. Материјал и упитник}

Како фразеолошке јединице нису нешто што се уобичајено и немаркирано користи, покушали смо да уз помоћ упитника који је био понуђен двема групама испитаника истражимо њихово познавање и евентулне способности за превод конкретних соматских фразеологизама. Испитаници су били студенти руског језика и књижевности треће и четврте године студија на Филозофском факултету у Нишу који као обавезни предмет на својим студијама имају Технику превођења. Прва група испитаника сусрела се са примерима соматских фразеологизама ван контекста, док је друга обухватала фразеологизме у конкретном реченичном контексту. На Ликертовој скали оценама од $1-6$ испитаници су оцењивали утицај познатости, транспарентности и познавања руске и српске културе на своје разумевање и могућност превођења датих соматских фразеологизама (превод је био опциони и у већини случајева делимично изостаје).

Упитник је био сачињен од 10 фразеологизама датих самостално као лексичке јединице ексцерпиране из Фразеолошког речника руског језика аутора Ю. А. Ларионове из 2014. године и у конкретном реченичном контексту:

1. На широкую ногу жить

2. В мгновение ока

3. В ногах правдын нет

4. В поте лийа

5. Висеть (держаться) на волоске

6. Выбить почву из-под ног

7. Вырастать в глазах

8. Глаза на лоб лезут

9. Нос не дорос

10. Отбиваться от рук

Дате соматске фразеологизме испитаници су оцењивали на основу следећих параметара: степен познатости, транспарентности значења, специфичне речи или фразе у саставу фразеологизма, познавања људске анатомије, познавања руске и српске културе. ${ }^{3}$ По могућности испитаници су имали и задатак да што тачније преведу фразеологизме на српски језик.

\section{3. Анализа резултата}

\section{Поређење експерименталних група}

Употребом т-теста најпре смо упоредили средње вредности циљних зависних варијабли између две експерименталне групе. Анализа степена познатости соматских фразеологизама (Табела 1) показала је значајне разлике између експерименталних група у следећим случајевима:

${ }^{3}$ Дате критеријуме као важне налазимо у литератури: Evans, V. (2006). Lexical concepts, cognitive models and meaning-construction. Cognitive Linguistics 17(4). 
a) фразеологизам в поте лица , $\mathrm{p}=.04$, у корист друге експерименталне групе групе;

б) фразеологизам выбить почву из-под ног, $\mathrm{p}=.01$, такође у корист друге групе;

в) фразеологизам вырастать в глазах, $\mathrm{p}=.04$, где је већи степен познатости такође забележен у другој групи;

г) фразеологизам нос не дорос, $\mathrm{p}=.23$, где је већи степен познатости забележен у првој групи испитаника;

д) фразеологизам отбиваться от $р у к, \mathrm{p}=.02$, где је већи степен познатости забележен у другој експерименталној групи.

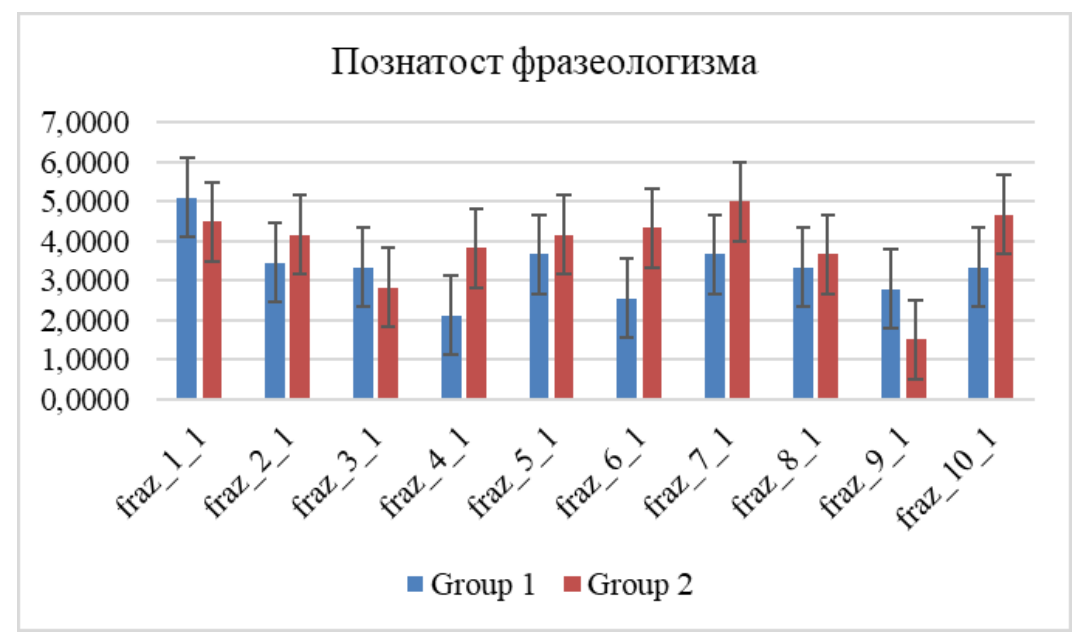

Слика 1. Познатост фразеологизама

Када говоримо о односу просечних процена познатости за све фразеологизме у две експерименталне групе, такође не уочавамо значајну разлику између група $(\mathrm{p}=.34)$. Овакав резултат указује да присуство реченичног контекста у првој експерименталној групи није било пресудно за процену познатости циљних соматских фразеологизама. То такође значи да су се испитаници више ослањали на своје знање руског језика и претходно искуство са датим фразеологизмима које је највероватније директно условљено и учесталошћу са којом се они могу наћи у наставним материјалима.

Тако соматски фразеологизам в поте лица који етимолошки сврставамо у групу библијских фразеологизама у свести говорника руског језика не подстиче на уочавање везе са еквивалентом у српском језику који је такође библијског порекла у зноју лица свог са значењем с тешком муком, напорно доћи до изиља.

Фразеологизам выбить почву из-под ног препознат је уз помоћ реченичног контекста као најприближнији српском еквиваленту губити тло под ногама, доспевати у тежак положај. 
Као један од примера код кога није изостао превод код обе групе испитаника истиче се фразеологизам вырастать в глазах (порасти у нечијим очима), притом успешније код испитаника који су овај фразеологизам оцењивали у датом реченичном контексту.

Степен познатости фразеологизма нос не дорос може се довести у везу са чињеницом да је у српском језику потенцијални еквивалент фразеологизам ни млечне зубе променио није, који је разговорног карактера. Значења попут врло млад, неискусан у српском језику покривена су изразом бити (још увек) млад и зелен, те због тога реченични контекст не игра пресудну улогу приликом превођења на српски језик.

Фразеологизам отбиваться от рук такође у српском језику има за еквивалент фразеологизам без соматске компоненте (измаћи контроли), те и у овом случају у одговорима испитаника изостаје превод овог фразеологизма.

Анализом транспарентности значења соматских фразеологизама утврдили смо значајне разлике између експерименталних група у следећим случајевима:

a) Фразеологизам в поте лииа, $\mathrm{p}=.03$, где је већа вредност забележена у другој групи;

б) Фразеологизам вырастать в глазах, $\mathrm{p}=.03$, где је већа вредност такође забележена у другој групи;

в) Фразеологизам нос не дорос, $\mathrm{p}=. .02$, где је већа вредност забележена у првој експерименталној групи.

Анализа утицаја познавања руске културе на разумевање циљних соматских фразеологизама открила је значајну разлику само у случају фразеологизма в поте лица, $\mathrm{p}=.047$, где је већа средња вредност забележена у другој експерименталној групи. Остале разлике нису достигле значајне вредности (p > .05).

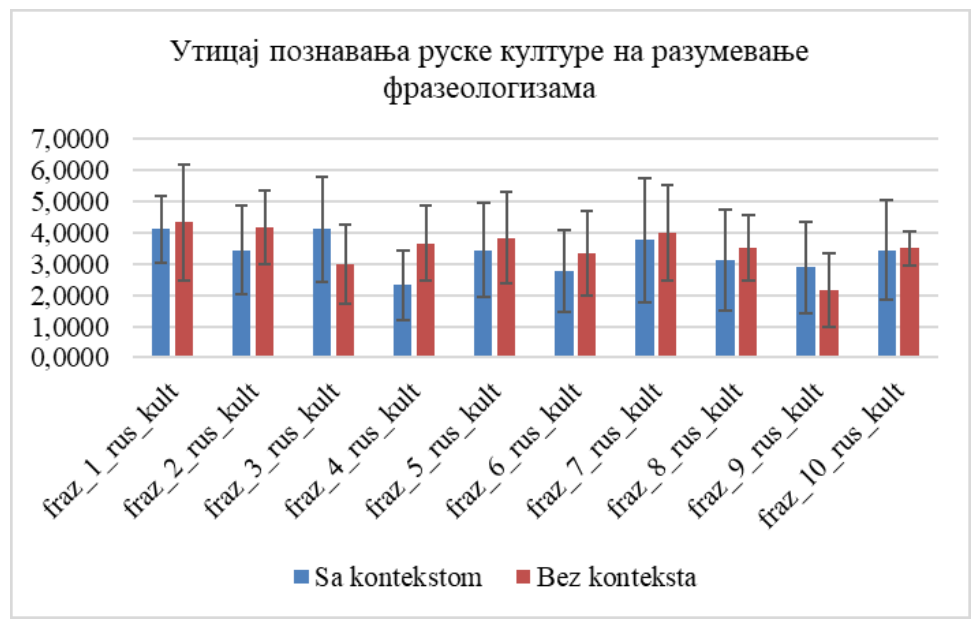

Слика 2. Утицај познавања руске културе на разумевање фразеологизама 
Анализом утицаја познавања српске културе на разумевање циљних фразеологизама нисмо идентификовали значајне разлике између експерименталних група.

Анализом утицаја познавања људске анатомије на разумевање фразеологизама идентификовали смо значајну разлику између експерименталних група једино у случају фразеологизма в поте лица $\mathrm{p}=.02$.

Анализом утицаја конкретних речи или фраза из самог фразеологизма на разумевање нисмо идентификовали значајне разлике између експерименталних група.

Други део наше анализе обухвата разлике унутар самих група. Статистички их представљамо на следећи начин:

\section{Прва експериментална група (са контекстом)}

Уз помоћ АНОВА теста са поновљеним мерењима (one way repeated measures ANOVA) упоредили смо средње оцене познатости циљних фразеологизама како бисмо идентификовали евентуалне статистички значајне разлике. АНОВА тест са поновљеним мерењима показао је значајан ефекат познатости $(F=5.94, p<$ .001 , partial eta squared $=.43)$, а додатне анализе су показале значајне разлике између следећих фразеологизама:

а) Фразеологизам 1 (на широкую ногу жить) и фразеологизам 4 (в поте лица), $\mathrm{p}=.02$;

б) Фразеологизам 1 и фразеологизам 6 (выбить почву из-под ног), $\mathrm{p}=.01$;

ц) Фразеологизам 1 и фразеологизам 9 (нос не дорос), $\mathrm{p}=.02$;

д) Фразеологизам 1 и фразеологизам 10 (отбиваться от рук), $\mathrm{p}=.03$.

У осталим поређењима није откривена статистичка значајност.

AНОВА тест са поновљеним мерењима показао је и значајан ефекат транспарентности значења $(\mathrm{F}=2,64, \mathrm{p}=.01$, partial eta squared $=.25)$, а додатне анализе су показале значајну разлику само између фразеологизма 1 и $6, \mathrm{p}=.03$ У осталим поређењима није откривена статистичка значајност.

Како бисмо испитали могуће разлике у степену утицаја познавања руске, односно српске културе на разумевање циљних соматских фразеологизама, спровели смо и АНОВА тест са поновљеним мерењима за сваки од фразеологизама посебно. Резултати су приказани у Табели 1. Једина значајна разлика идентификована је у случају другог фразеологизма, што указује да је испитаницима познавање обе културе било подједнако важно за разумевање циљних соматских фразеологизама.

Табела 1. Утицај руске и српске културе на разумевање изиљних СФ

\begin{tabular}{|l|c|c|c|c|c|}
\hline \multirow{2}{*}{ Фразеологизам } & \multicolumn{2}{|c|}{$\begin{array}{c}\text { Познавање руске } \\
\text { културе }\end{array}$} & \multicolumn{2}{|c|}{$\begin{array}{c}\text { Познавање српске } \\
\text { културе }\end{array}$} & \multirow{2}{*}{$\mathrm{P}$} \\
\cline { 2 - 5 } & $\mathrm{M}$ & $\mathrm{SD}$ & $\mathrm{M}$ & $\mathrm{SD}$ & \\
\hline Фразеологизам1 & 4.11 & 1.05 & 4.55 & 1.13 & .10 \\
\hline Фразеологизам2 & 3.44 & 1.42 & 3.89 & 1.69 & .04 \\
\hline
\end{tabular}




\begin{tabular}{|l|c|c|c|c|c|}
\hline Фразеологизам3 & 4.11 & 1.69 & 4.22 & 1.30 & .68 \\
\hline Фразеологизам4 & 2.33 & 1.11 & 2.67 & 1.32 & .20 \\
\hline Фразеологизам5 & 3.44 & 1.51 & 4.00 & 1.32 & .18 \\
\hline Фразеологизам6 & 2.78 & 1.30 & 3.00 & 1.41 & .17 \\
\hline Фразеологизам7 & 3.78 & 1.99 & 3.56 & 1.81 & .17 \\
\hline Фразеологизам8 & 3.11 & 1.62 & 3.67 & 1.66 & .10 \\
\hline Фразеологизам9 & 2.89 & 1.45 & 3.22 & 1.30 & .20 \\
\hline Фразеологизам10 & 3.44 & 1.59 & 3.67 & 1.50 & .35 \\
\hline
\end{tabular}

АНОВА тест са поновљеним мерењима није показао никакве значајне разлике у оцени значаја познавања људске анатомије за разумевање циљних јединица. Исти резултат је забележен и при анализи значаја конкретних речи или фраза из фразеологизама.

\section{Друга експериментална група (без контекста)}

АНОВА тест са поновљеним мерењима показао је значајан ефекат познатости и у другој експерименталној групи $(\mathrm{F}=5.24, \mathrm{p}<.001$, partial eta squared $=.51)$, a додатне анализе су показале значајне разлике између следећих фразеологизама:

a) Фразеологизам 7 и фразеологизам $9, \mathrm{p}=.01$;

б) Фразеологизам 9 и фразеологизам 10, $\mathrm{p}=.01$.

У осталим поређењима није откривена статистичка значајност.

АНОВА тест са поновљеним мерењима показао је значајан ефекат транспарентности значења фразеологизма и у другој експерименталној групи ( $\mathrm{F}=5.07$, $\mathrm{p}<.001$, partial eta squared $=.50$ ), а додатне анализе су показале значајне разлике између следећих фразеологизама:

а) Фразеологизам 2 и фразеологизам $9, \mathrm{p}=.02$;

б) Фразеологизам 7 и фразеологизам 9, $\mathrm{p}=.02$.

ц) Фразеологизам 9 и фразеологизам $10, \mathrm{p}=.01$.

У осталим поређењима није откривена статистичка значајност.

Како бисмо испитали могуће разлике у степену утицаја познавања руске и српске културе на разумевање циљних соматских фразеологизама, спровели смо и AНОВА тест са поновљеним мерењима за сваки од фразеологизама посебно. Резултати су приказани у Табели 2. Једина значајна разлика идентификована је у случају првог фразеологизма (на широкую ногу жить), што указује да је испитаницима познавање обе културе било подједнако важно за разумевање циљних фразеологизама. Уочена веза између српског еквивалента живети на високој нози резултирала је успешним преводом у највећем броју одговора испитаника. 
Табела 2. Разлике у степену утицаја руске и српске културе

\begin{tabular}{|l|c|c|c|c|c|}
\hline \multirow{2}{*}{ Фразеологизам } & \multicolumn{2}{|c|}{$\begin{array}{c}\text { Познавање руске } \\
\text { културе }\end{array}$} & \multicolumn{2}{c|}{ Познавање српске } & \multirow{2}{*}{$\mathrm{p}$} \\
\cline { 2 - 5 } & $\mathrm{M}$ & $\mathrm{SD}$ & $\mathrm{M}$ & $\mathrm{SD}$ & \\
\hline Фразеологизам1 & 4.33 & 1.86 & 4.50 & 1.87 & .002 \\
\hline Фразеологизам2 & 4.16 & 1.17 & 4.00 & 1.26 & .36 \\
\hline Фразеологизам3 & 3.00 & 1.26 & 3.00 & 1.26 & - \\
\hline Фразеологизам4 & 3.67 & 1.21 & 3.50 & 1.22 & .36 \\
\hline Фразеологизам5 & 3.83 & 1.47 & 3.50 & 1.38 & .18 \\
\hline Фразеологизам6 & 3.33 & 1.37 & 3.33 & 1.37 & - \\
\hline Фразеологизам7 & 4.00 & 1.55 & 4.00 & 1.55 & - \\
\hline Фразеологизам8 & 3.50 & 1.05 & 3.00 & 0.89 & .08 \\
\hline Фразеологизам9 & 2.17 & 1.17 & 2.17 & 1.17 & - \\
\hline Фразеологизам10 & 3.50 & 0.55 & 3.50 & 0.55 & - \\
\hline
\end{tabular}

AНОВА тест са поновљеним мерењима ни у другој експерименталној групи није показао никакве значајне разлике у оцени значаја познавања људске анатомије за разумевање циљних јединица. Исти резултат је такође забележен и при анализи значаја конкретних речи или фраза из фразеологизама.

\section{Закључна разматрања}

Како је предмет нашег истраживања био усмерен на анализу разумевања соматских фразеологизама, најважнија, а неочекивана, напомена односи се на чињеницу да у највећем броју случајева контекст није у значајној мери утицао на разумевање и способност испитаника да преведу дате соматске фразеологизме.

Посебно бисмо издвојили три соматска фразеологизма из упитника који су у 95\% случајева остала без превода: фразеологизам број 4 (в поте лииа) - библијског карактера, очекивано повезивање са српским у зноју лицза свога; фразеологизам број 6 (выбить почву из под ног) - тачно превео само један испитаник, остатак као главну потешкоћу препознаје поново реч библијског карактера почва; фразеологизам број 9 (нос не дорос) - фразеологизам разговорног карактера који највероватније утиче на немогућност проналажења преводног еквивалента у српском језику (ни млечне зубе променио није). Дакле, као правилност се истиче недовољно познавање лексике библијског порекла. Ауторка Наташа Вуловић у раду Српска фразеологија и религија (Вуловић 2015: 38) истиче управо природу религијске компоненте као једну од најважнијих за разумевање значења фразеологизама.

Изнети статистички подаци начелно наглашавају значај следећих фактора: неопходност не само доброг познавања оба језика, већ и културе односно слике све- 
та двају блиских словенских народа. Утицај контекста на коначне и најтачније могућности превођења у наведеним примерима је занемарљив. Дато истраживање на тренутном нивоу посматрамо као смерницу за даља, обимнија и шира истраживања, где би нам већи број истраживаних фактора предочио јаснију слику о перцепцији соматских фразеологизама код говорника руског језика као страног.

\section{Цитирана литература}

Алефиренко Николай Ф. Фразеология в свете современных лингвистических парадигм. Москва: Элпис, 2008.

[Alefirenko Nikolai F. Frazeologiiâv svete sovremennykh lingvisticheskikh paradigm. Moskva: Ėlpis, 2008]

Виноградов Виктор В. Перевод: общие и лексические вопросы: Учебное пособие. 2-е изд., перераб. Москва: КДУ, 2004.

[Vinogradov Viktor V. Perevod: obshchie i leksicheskie voprosy: Uchebnoe posobie. 2-e izd., pererab. Moskva: KDU, 2004]

Вуловић, Наташа. Српска фразеологија и религија. Београд: Институт за српски језик САНУ, 2015.

[Vulović, Nataša. Srpska frazeologija i religija. Beograd: Institut za srpski jezik SANU, 2015]

Đorđević, Radmila. Uvod u kontrastiranje jezika. Beograd: Filološki fakultet Univerziteta u Beogradu, 2004.

Комиссаров Вилен Н. Теория перевода (лингвистические аспекты). Москва: Наука, 1990.

[Komissarov Vilen N. Teoriiā perevoda (lingvisticheskie aspekty). Moskva: Nauka, 1990]

Кунин Александр В. Курс фразеологии современного английского языка. Москва: Феникс, 1996.

[Kunin Aleksandr V. Kurs frazeologii sovremennogo angliǔskogo iāzyka.. Moskva: Feniks, 1996]

Menac, A. Hrvatsko-talijanski frazeoloski rjeenik. Zagreb: Zavod za lingvistiku Filozofskoga fakulteta Sveucilista u Zagrebu, 1995.

Мршевић-Радовић, Драгана. Фразеолошке глаголско-именичке синтагме у савременом српскохрватском језику. Београд: Филолошки факултет, 1987.

[Mršević-Radović, Dragana. Frazeološke glagolsko-imeničke sintagme u savremenom srpskohrvatskom jeziku. Beograd: Filološki fakultet, 1987]

Мршевић-Радовић, Драгана. Фразеологија и национална култура. Београд: Чигоја штампа, 2008.

[Mršević-Radović, Dragana. Frazeologija i nacionalna kultura. Beograd: Čigoja štampa, 2008]

Ройзензон Леонид И. Лекции по общей и русской фразеологии. Самарканд: М-во высш. и сред. спец. образования. Самарк. гос. ун-т им. А. Навои, 1973.

Caillies, Stephanie, Butcher, Kirsten. Processing of Idiomatic Expressions: Evidence for a New Hybrid View. Metaphor and Symbol, 22(1), 2007: 79-108.

Cienki, Alan. Frames, Idealized Cognitive Models, and Domains. In The Oxford Handbook of Cognitive linguistics. Oxford: Oxford University Press, 2007: 170 -187.

Evans, Vyvyan. Lexical concepts, cognitive models and meaning-construction. Cognitive Linguistics 17(4), 2006: 491 - 534. 


\title{
Извори
}

Ларионова, Юлия А. Фразеологический словарь современного русского языка. Москва: Аделант, 2014.

[Larionova, Ûliâ A. Frazeologičeskij slovar' sovremennogo russkogo âzyka. Moskva: Adelant, 2014]

Оташевић, Ђорђе. Фразеолошки речник српског језика. Нови Сад: Прометеј, 2012.

[Otašević, Đorđe. Frazeološki rečnik srpskog jezika. Novi Sad: Prometej, 2012]

\section{Эмилия Йович}

\section{ОБ ОСОБЕННОСТЯХ ТЕХНИКИ ПЕРЕВОДА СОМАТИЧЕСКИХ ФРАЗЕОЛОГИЗМОВ С РУССКОГО НА СЕРБСКИЙ ЯЗЫК}

\begin{abstract}
Резюме
Предметом нашего исследования являются соматические фразеологизмы, в частности анализ факторов, влияющих на их понимание и возможность перевода с русского языка на сербский теми носителями, для которых русский язык не является родным. Выделение основных принципов, определяющих возможности перевода этих конкретных лексических единиц в сознании говорящих русским языком как иностранным, является одной из основных задач нашей работы. Как правило, фразеологизм переводится фразеологизмом, но это, как известно, не всегда возможно, поэтому для каждого конкретного случая перевода соматических фразеологизмов используются разные приемы. Целью нашей работы является определение основных факторов, влияющих на возможность перевода соматических фразеологизмов говорящими русским языком как иностранным.
\end{abstract}

Ключевые слова: соматические фразеологизмы, техника перевода, русский язык, сербский язык. 